\title{
Dental Students' Familiarity with the Medical Management of Dental Patients at Brazilian Dental Schools
}

\author{
Paula Caetano Araújo, M.S.; Cléa Adas Saliba Garbín, Ph.D.; Suzely Adas Saliba Moimaz, \\ Ph.D.; Nemre Adas Saliba, Ph.D.; Renato Moreira Arcieri, Ph.D.
}

Abstract: Drug therapy in dentistry is essential for patients' treatment and requires special care by dentists, so it must be part of a well-grounded education for predoctoral dental students. The aim of this study was to evaluate the knowledge of undergraduate students at dental schools in Brazil about the use of drugs in dental practice. The sample universe was comprised of all undergraduates enrolled in the last year of the dentistry course in three universities in $2010(n=253)$. Inclusion criteria were students in their last year of enrollment and who agreed to participate in the research. The results were analyzed on Epi Info 3.5.1 software. Analyses were conducted with chi-square, Friedman, and Wilcoxon tests. Slightly more than half of the participants (51.9 percent) reported the ideal dose of anesthetic for a normal patient. However, their difficulties increased when asked about the relationship between the anesthetic and patients with systemic disease or those needing special care. Regarding drugs that usually cause allergic attack, only 29.2 percent and 36.6 percent, respectively, cited methyl methacrylate and latex. This study found that the knowledge of these undergraduates about the questions was deficient, so dental education should include more theoretical and clinical practice in recognizing the patient's medical needs.

Ms. Araújo is a doctoral candidate, Preventive and Social Dentistry Postgraduate Program, Department of Infant and Social Dentistry, Faculty of Dentistry, Araçatuba Dental School, UNESP, Araçatuba, São Paulo State, Brazil; Dr. Garbín is Coordinator of Public Health Postgraduation Program, Department of Infant and Social Dentistry, Faculty of Dentistry, Araçatuba Dental School, UNESP, Araçatuba, São Paulo State, Brazil; Dr. Moimaz is Professor and Vice Coordinator of Public Health Postgraduation Program, Department of Infant and Social Dentistry, Faculty of Dentistry, Araçatuba Dental School, UNESP, Araçatuba, São Paulo State, Brazil; Dr. Saliba is Professor, Department of Infant and Social Dentistry, Faculty of Dentistry, Araçatuba Dental School, UNESP, Araçatuba, São Paulo State, Brazil; and Dr. Arcieri is Adjunct Professor, Department of Infant and Social Dentistry, Faculty of Dentistry, Araçatuba Dental School, UNESP, Araçatuba, São Paulo State, Brazil. Direct correspondence and requests for reprints to Ms. Paula Caetano Araújo, Street José Bonifácio, 1193, Vila Mendonça, Araçatuba-SP, Brazil 16015-050; paulinhacaetano@hotmail.com.

Keywords: dental anesthesia, dental materials, drug therapy in dentistry, dental students, Brazil

Submitted for publication 6/3/12; accepted 7/27/12

$\mathrm{D}$ rug therapy in dentistry requires special attention because the use of drugs in dental treatment is growing and the field is becoming more complex. ${ }^{1}$ Among the most frequent uses is that of anesthetics for pain., ${ }^{2,3}$ It is important that dental professionals are familiar with the drug of choice for the specific needs of each patient. ${ }^{4,5} \mathrm{~A}$ study done by Vasconcellos et al. ${ }^{4}$ found that health professionals were often uncertain about choosing the proper anesthetic formula, and this problem was worst related to patients with certain systemic disorders.

Many dentists prefer to use only one type of local anesthetic for all dental procedures, ${ }^{6}$ and the consequences of that choice can lead to clinical complications in healthy or unhealthy patients, such as trismus, hematoma, tissue necrosis, and allergy. ${ }^{7,8}$ Syncope, bronchospasm, myocardial infarction, and anaphylactic shock may also occur. ${ }^{5,9}$ However, these manifestations can be avoided in all types of patients with preventive actions such as detailed anamneses, correct positioning of patient, aspiration with positive visualization, slow IV injections, and total specific doses based on the systemic condition of each individual. ${ }^{10}$ Some authors have pointed out the need for caution in the use of drugs for certain patient groups, such as pregnant women (anesthetics and antibiotics ${ }^{11-13}$ ), patients with nonmedicated hyperthyroidism, ${ }^{14}$ those who have asthma and use corticosteroids, ${ }^{15}$ and those using tricyclic antidepressants. ${ }^{16,17}$ It is relevant to remember that many drugs or substances used in dentistry, such as penicillin, methyl methacrylate (monomer of acrylic resin), and latex, are capable of causing allergic reactions. ${ }^{18}$

Dentists must make complex decisions regarding anesthesia that may influence the oral health equilibrium and maintenance of their patients' systemic health. ${ }^{19-22}$ Evaluating the clinical risk of a patient has never been as important as in recent years. Therefore, the aim of our study was to evaluate the 
knowledge of dental undergraduates enrolled in their last year of three dental schools in Brazil about the appropriate use of local anesthetics, the indications and contraindications of drugs in certain medical situations (especially pregnancy), and the management of patients with allergies in clinical dental practice. The results of this study may improve the quality of dental education and the training of future dentists.

\section{Methodology}

This cross-sectional study was performed at three Brazilian dental schools: a federal, a state, and a private university. The study received the approval of the Ethics Committee in Human Research (FOA/ UNESP), process code: FOA-01374/2010. After the approval, the directors of the dental universities were informed about the aim of this research; then, they authorized the study.

The instrument used was a structured questionnaire with some of the questions based on the work of Vasconcellos et al. ${ }^{4}$ The questionnaire was written in Portuguese, and it was conducted in classrooms of the three universities. The same researcher was present at all applications of the questionnaire, avoiding exchange of information among the students. The questionnaire included open and closed questions about undergraduates' perceptions of the use of anesthetics, allowed maximum doses, their use on patients with systemic disorders or those needing special care, and their adverse effects (allergic attacks and teratogenicity).

A total of 253 students at the three universities were invited to participate in the study. The inclusion criteria were enrollment in the last year of their course at dental school and agreement to participate in the research. At the end of the study, the faculty at the three universities were given the results of their students' evaluation, and the students were sent a document containing the correct answers. The descriptive statistical analysis involved prevalence calculation, using Epi Indo 3.5.1 software. ${ }^{23}$ Chisquare, Friedman, and Wilcoxon tests were used to statistically verify significant differences among the responses. Statistical significance was set at $p<0.05$, with two-tailed tests.

\section{Results}

The response rate was 83 percent $(n=210)$. The results showed that slightly more than half of the respondents (51.9 percent) stated correctly the maximum permissible dose of anesthetic for a healthy patient weighing $70 \mathrm{~kg}$. In relation to patients with systemic disorders, we found that 59.5 percent of the responding students accurately chose prilocaine with felypressin for asthmatic patients who depend on corticosteroids (Table 1). Among these students, 23.1 percent indicated the use of local anesthetics with adrenergic vasoconstrictors for patients with hyperthyroidism. The chi-square test revealed statistically significant differences among the universities $(p<0.01)$. We also noted the undergraduates' first choice of anesthetic formula for patients using tricyclic antidepressant drugs (Table 1).

When these students were asked about the treatment of pregnant patients, 63.8 percent did not know the allowed maximum dose of anesthetic with vasoconstrictor. Only 19.5 percent said that prilocaine must be avoided during pregnancy. However, 79.6 percent and 72.8 percent, respectively, correctly indicated the best time for dental procedures on pregnant women and the drugs that must be avoided during pregnancy. As for substances and drugs that commonly cause allergic attacks, although 78.2 percent cited penicillin, only 29.2 percent and 36.6 percent, respectively, cited methyl methacrylate and latex. There were statistically significant differences among respondents from the three universities regarding penicillin and latex (chi-square test). The

Table 1. Responses of study participants about anesthetic of choice for patients with asthma who are using corticosteroids and users of tricyclic antidepressants, by percentage of total respondents

\begin{tabular}{|c|c|c|c|c|}
\hline & $\begin{array}{c}\text { Lidocaine } \\
+ \\
\text { Felypressin }\end{array}$ & $\begin{array}{c}\text { Prilocaine } \\
+ \\
\text { Noradrenaline }\end{array}$ & $\begin{array}{c}\text { Mepivacaine } \\
+ \\
\text { Adrenaline }\end{array}$ & $\begin{array}{c}\text { Prilocaine } \\
\quad+ \\
\text { Adrenaline }\end{array}$ \\
\hline Asthmatic patients & $15.7 \%$ & $59.5 \%$ & $9.0 \%$ & $7.6 \%$ \\
\hline Tricyclic antidepressant users & $18.6 \%$ & $13.8 \%$ & $47.6 \%$ & $9.0 \%$ \\
\hline
\end{tabular}

Note: Among these students, 8.2 percent did not answer the question related to asthmatic patients, and 11 percent did not answer the question related to users of tricyclic antidepressant drugs. 
state university had the highest number of students who reported that penicillin can cause allergic attacks $(p<0.001)$, while the opposite was observed for latex $(p<0.001)$. There were also statistically significant values found by the Friedman $(p<0.001)$ and Wilcoxon tests (Table 2) for correct answers of federal university students compared with the other universities: the federal university had the lowest levels of accuracy of the three universities.

\section{Discussion}

The students who were evaluated in this study had difficulties responding to the questions on the appropriate use of local anesthetics and management of patients with allergies. However, they demonstrated knowledge about the best period for dental treatment during pregnancy and the contraindication of tetracycline. These findings illustrate the importance of dental education for the future professionals. A wellgrounded academic education in dentistry results in dentists' giving the proper care during patients' treatment. ${ }^{24}$ Knowledge of the use of drugs and their application to patients with systemic disease is essential because appropriate conduct based on ethics and professional responsibility is fundamental to good dental practice and must include well-established knowledge of the use of anesthetics for healthy patients as well as for those with pathologies.

In relation to the maximum dose of anesthetic with vasoconstrictor for patients without systemic complications, 51.9 percent of the participants answered correctly that eight cartridges of lidocaine 2 percent plus adrenaline 1:100,000 could be administrated to a healthy patient weighing $70 \mathrm{~kg}$ without manifesting an adverse reaction. This dose is that advised by Malamed. ${ }^{15}$

Only three groups of patients with systemic disorders were evaluated in this study: asthmatics who depend on corticosteroids, patients who have nonmedicated hyperthyroidism, and users of tricyclic antidepressant drugs. For the first group (asthmatics), 59.5 percent of the participants answered that the most frequently indicated anesthetic formula was prilocaine with felypressin (Table 1) - also the first choice for Malamed. ${ }^{15}$ Adrenergic or sympathomimetic vasoconstrictors have antioxidants (sodium bissulfite) in their formulations, and they are related to allergic reactions in this kind of patients..$^{15}$ It is also important to emphasize that patients who use corticosteroids are more likely to present Candida
Table 2. Probabilities for correct answers given by study participants at dental schools at three Brazilian universities

\begin{tabular}{lc} 
& Probability \\
\hline $\begin{array}{l}\text { Federal university } \\
\text { Private university }\end{array}$ & $0.002 *$ \\
$\begin{array}{l}\text { Federal university } \\
\text { State university }\end{array}$ & $0.003^{*}$ \\
Private university & \\
State university & 0.084 \\
*Wilcoxon test, $\mathrm{p}<0.05$ & \\
\end{tabular}

albicans on the mucous membranes and tongue,$^{25}$ so dentists should be aware of this oral manifestation. However, when the study participants were asked about indications for the use of local anesthetics with adrenergic vasoconstrictors for patients with nonmedicated hyperthyroidism, only 23.1 percent agreed with this association. For nonmedicated patients with hyperthyroidism, this combination must be avoided because of the indirect or direct natural action of the thyroid hormones on the cardiovascular system. ${ }^{14}$ It is important to mention that 35.6 percent of the study participants did not answer this question and 76.4 percent did not justify their choice of this combination. Among the 23.6 percent who justified this question, only 6.7 percent did so correctly. With further regard to the nonmedicated hyperthyroidism patients, there was a statistically significant difference for undergraduates from the private school $(p<0.01$, based on the chi-square test). These students gave the highest number of incorrect answers compared with the other two universities with respect to the use of local anesthetics with adrenergic vasoconstrictors.

Nearly half the participants ( 47.6 percent) said that prilocaine with felypressin is the anesthetic of choice for patients taking tricyclic antidepressants (Table 1). This combination is correct because tricyclic antidepressants may be synergistic for the cardiovascular functions of vasopressors administrated exogenously. ${ }^{16} \mathrm{It}$ is also important to mention that patients with hyperthyroidism and tricyclic antidepressants users are xerostomic, ${ }^{26}$ so there is also a treatment implication involved, requiring attention and observation by the dentists. Vasconcellos et al. ${ }^{4}$ found that 6.8 percent of undergraduate dental students cited lidocaine with adrenaline as the anesthetic of choice for patients on tricyclic antidepressant drugs, while 2.3 percent and 1.1 percent, respectively, mentioned prilocaine with felypressin as the most often indicated 
anesthetic formula for asthmatic patients and those who have nonmedicated hyperthyroidism.

Concerning the use of drugs in dental practice for patients needing special care, one group requiring the dentist's attention is pregnant women, especially concerning the use of local anesthetic solutions. It must be emphasized that, during the treatment of this patient, there are two individuals (woman and fetus) in the dental chair - not just one. Rood ${ }^{11}$ affirmed that two cartridges of anesthetic with vasoconstrictor is the maximum allowable dosage for pregnant patients to avoid adverse reactions and toxicity for woman and fetus. Among the total respondents in our study, 63.8 percent failed to answer correctly a question about this maximum allowable dosage for pregnant patients, emphasizing the difficulty these students have about determining the correct use of this drug for this group of patients.

As for the anesthetic that must be avoided during pregnancy due to its crossing the placental barrier, only 19.5 percent of participants in our study cited prilocaine. According to Rood, ${ }^{11}$ prilocaine reaches the placenta more easily than other local anesthetics (lidocaine, mepivacaine, and bupivacaine). The prilocaine has a toxic metabolite, the o-toluidine, that can lead to methemoglobin by the direct oxidation of hemoglobin. ${ }^{27}$ This anesthetic must be avoid in pregnancy because of the risk of the fetus contracting this disease. Therefore, dental appointments should be scheduled preferably during the second trimester of pregnancy because it is during this period that organogenesis is completed and the fetus is developed. ${ }^{13}$ The undergraduates in our study seemed to be aware of this fact because 79.6 percent answered correctly the question about the best period of pregnancy for dental treatment. Also for pregnant patients, there is a contraindication for tetracycline. ${ }^{12}$ Most undergraduates (72.8 percent) in our study confirmed the contraindication of this drug. Penicillin, erythromycin, and clindamycin do not have teratogenic effects on the fetus and can be safely administrated to pregnant patients. ${ }^{28}$

Considering that local anesthetics, analgesics, anti-inflammatory drugs, and antibiotics are the medications most frequently used in dentistry and that they are intrinsically allergenic and can cause anaphylactic reactions, the odds are high that some patients will be at risk. Among the drugs in dentistry, the ones most related to allergic reactions are lidocaine and penicillin. Latex and methyl methacrylate are also allergenic, so they need special attention by the dentist. ${ }^{18}$ The majority of participants (78.2 percent) in our study responded correctly about penicillin's tendency to cause immune reactions. However, only 29.2 percent and 36.6 percent, respectively, reported that methyl methacrylate and latex can cause allergic attacks. Answers from students in private and state universities about penicillin and latex allergies received statistically significant values (chi-square test), but the state university had the highest number of undergraduates who stated that penicillin can cause allergic attacks $(p<0.001)$, while the opposite was observed for latex $(\mathrm{p}<0.001)$.

Recognizing that this questionnaire included other variables, we applied the Friedman test (significance level $=0.05$ ) and found that $p<0.001$, indicating that there were statistically significant differences among the correct answers given by the respondents from the three universities. The Friedman test did not indicate the direction of the differences, so, using the Wilcoxon test, we verified that the federal university had the lowest index of hits compared with the other two universities (Table 2).

\section{Conclusion}

Considering the results of our study, we reached the following conclusions. First, slightly more than half of the dental undergraduates in the study were knowledgeable about the use of anesthetics on patients without systemic complications. The same was observed for patients with asthma who depend on corticosteroids. Second, a large number of students did not know the anesthetic of choice for users of tricyclic antidepressants. Third, few students knew the anesthetic of choice for nonmedicated hyperthyroidism patients. Fourth, most of the students were not aware of the anesthetic formula that must be avoided during pregnancy or the maximum permissible dose of anesthetic cartridges. The majority affirmed correctly the best period for dental treatment during pregnancy, and there was also a high number to contraindicate tetracycline for this group of patients. Finally, few students realized that latex and methyl methacrylate can cause an allergic attack.

Dental education should emphasize the importance of pharmacology in the predoctoral curriculum, leading to a responsible and ethical clinical practice. A higher priority should be given to the clinical use of drugs, highlighting future situations that the dentist might face in professional practice and leading to a well-established relationship between theory and the clinical needs of the dental office. 


\section{Acknowledgments}

The authors would like to thank CAPES (Coordination for the Improvement of Higher Level Personnel) for financial support for this study through a master's degree scholarship.

\section{REFERENCES}

1. Antunes AA, Vasconcellos RJH, Medeiros MF, Genu PR. Conhecimento dos alunos de graduação da FOP/UPE em relação à dosagem anestésica local. Rev Cir Traumat Buco-Maxilo-Fac 2007;7(1):71-8.

2. Oliveira AEM, Simone JL, Ribeiro RA. Pacientes hipertensos e a anestesia na Odontologia: devemos utilizar anestésicos locais associados ou não com vasoconstritores? HU Revista 2010;36(1):69-75.

3. Brand HS, Baart JA, Maas NE, Bachet I. Effect of a training model in local anesthesia teaching. J Dent Educ 2010;74(8):876-9.

4. Vasconcellos RJH, Antunes AA, Medeiros MF, Genu PR. Conhecimento dos alunos de graduação da FOP/UPE em relação à indicação de anestésicos locais para pacientes especiais. Odonto 2010;18(35):30-6.

5. Rosenberg M, Orr DL II, Starley ED, Jensen DR. Student-to-student local anesthesia injections in dental education: moral, ethical, and legal issues. J Dent Educ 2009;73(1):127-32.

6. Silva SREP, Andrade APRCB, Costa FP, Cunha RS, Politano GT, Pinheiro SL, Imparato JCP. Avaliação da técnica anestésica local utilizada por alunos de graduação em odontologia. ConScientiae Saúde 2010;9(3):469-75.

7. Arantes SB, Souza JA. Acidentes anestesiológicos em odontologia. Odontol Mod 1990;17(3):16-9.

8. Brand HS, Bekker W, Baart JA. Complications of local anaesthesia: an observational study. Int J Dent Hyg 2009;7:270-2.

9. Vasconcellos RJH, Nogueira RVB, Leal AKR, Oliveira CTV, Bezerra JGB. Alterações sistêmicas decorrentes do uso da lidocaína e prilocaína na prática odontológica. Rev Cir Traumat Buco-Maxilo-Fac 2002;2(1):13-9.

10. Rood JP. Adverse reaction to dental local anesthetic injection: "allergy" is not the cause. Br Dent J 2000;189(7): $380-4$.

11. Rood JP. Local analgesia during pregnancy. Dent Update 1981;8(7):483-5.

12. Andrade J, Mendes CCL. Medicamentos cardiovasculares na gravidez, parto e puerpério. Rev Soc Cardiol Estado São Paulo 1994;4(6):581-8.

13. Drugs in dentistry. In: Compendium of pharmaceuticals and specialties. 37th ed. Ottawa: Canadian Pharmaceutical Association, 2002:L26-9.
14. Pérusse R, Goulet JP, Turcotte JY. Contraindications to vasoconstrictors in dentistry: part II. hyperthyroidism, diabetes, sulfite sensitivity, cortico-dependent asthma, and pheochromocytoma. Oral Surg Oral Med Oral Pathol 1992;74(5):687-91.

15. Malamed SF. Manual de anestesia local. 5th ed. Rio de Janeiro: Elsevier, 2005.

16. Jastak JT, Yagiela JA. Vasoconstrictors and local anesthesia: a review and rational use. J Am Dent Assoc 1983;107(4):623-30.

17. Chioca LR, Segura RCF, Andreatini R, Losso EM. Antidepressivos e anestésicos locais: interações medicamentosas de interesse odontológico. Rev Sul-Bras Odontol 2010;7(4):466-73.

18. Gomez RS, Maia DMF, Lehman LFC, Santoro DR, Azeredo P, Castro WH. Emergências médicas no consultório odontológico. Rev CROMG 1999;5(1):4-10.

19. Jolly DE. Recognition of medical risk in the dental patient. Anesth Prog 1995;42(3-4):90-2.

20. Nascimento EM, Santos MF, Martins VM, Cavalcanti AL, Menezes VA, Granville-Garcia AF. Abordagem odontológica de pacientes com hipertensão: um estudo de intervenção. RFO 2011;16(1):30-5.

21. Araújo LC, Bavaresco CS. Verificação do conhecimento e da conduta de odontólogos em relação ao manejo do paciente cardiopata na atenção primária à saúde. Rev APS 2011;14(2):197-206.

22. Moore PA, Boynes SG, Cuddy MA, Giovannitti JA Jr, Zovko J. Educational experiences and preparedness in dental anesthesia: five-year outcome assessment and conclusions. J Dent Educ 2009;73(12):1379-86.

23. Centers for Disease Control and Prevention. EpiInfo 3.5.1 [computer program]. At: www.lampada.uerj.br/epiinfo/ instala341.htm. Accessed: May 4, 2012.

24. Pires CP, Ferraz MB, de Abreu MH. Translation into Brazilian Portuguese, cultural adaptation, and validation of the oral health impact profile (OHIP-49). Braz Oral Res 2006;20(3):263-8.

25. Knight L, Fletcher J. Growth of Candida albicans in saliva: stimulation by glucose associated with antibiotics, corticosteroids, and diabetes mellitus. J Infect Dis 1971;123(4):371-7.

26. Greenspan D. Xerostomia: diagnosis and management. Oncology (Williston Park) 1996;10(3 Suppl):7-11.

27. Vasters FG, Eberhart LH, Koch T, Kranke P, Wulf H, Morin AM. Risk factors for prilocaine-induced methaemoglobinaemia following peripheral regional anaesthesia. Eur J Anaesthesiol 2006;23(9):760-5.

28. Russell SL, Mayberry LJ. Pregnancy and oral health: a review and recommendations to reduce gaps in practice and research. MCN Am J Matern Child Nurs 2008;33(1):32-7. 